\title{
EARLY QUILL LAKE ORNITHOLOGISTS
}

C. STUART HOUSTON, 863 University Drive, Saskatoon, Saskatchewan, S7N $0 J 8$.

The first naturalists to explore the Quill Lakes area intensively were John Farwell Ferry and R. Magoon Barnes in 1909. Both were Americans. Ferry came to collect bird skins and eggs in order to prepare habitat cases for the Field Museum of Natural History in Chicago, Illinois. He came first to Prince Albert where he collected from 26 May to 7 June. He was then told of the almost unlimited wealth of bird life at the Quill Lakes, and he collected there from 9 June through 11 August, apart from a two week absence in late July. Ferry's observations, of great historic importance, were published in The Auk 27:185-204, April 1910.

The grandson of a wealthy dry goods merchant, Ferry had graduated in civil engineering from Yale University in 1901. After one year working for the Y.M.C.A. and two years in business, Ferry decided to indulge his love for nature and became a collector for the United States Biological Survey for two years. Early in 1906 he joined the Field Museum of Natural History in Chicago. Immediately preceding his Quill Lakes trip he had been on a collecting trip to the Caribbean islands along the north shore of Venezuela, where he had collected eight bird species not previously described, one of which was named Caereba ferryi in his honour.

During much of his Quill Lakes trip, Ferry had as his companion Richard Magoon Barnes, a lawyer for the
Central Illinois Railroad at Lacon, Illinois, and an enthusiastic collector of birds' eggs.

In 1909 the plains around the Quill Lakes were beginning to recover from the ravages of almost yearly prairie fires. Ferry wrote: "Poplar thickets or 'bluffs' as they are locally termed, are a characteristic feature of the landscape. Toward the southern end of the lake they almost entirely disappear, while around the northern edge, they run together to such an extent that the term continuous woodland might be used to describe a large portion of the area they cover." However, most aspen bluffs contained young, short trees, for crow nests "were usually placed six or seven feet from the ground in poplar thickets ...."

Ferry and Barnes were assisted by Herbert C. Clark, a local farmer whose younger brother had watched a pair of Whooping Cranes along the east shore of Big Quill nearly all spring. R. M. Barnes saw a Whooping Crane at the north shore of the lake on 14 June 1909. By 1913 William T. Hornaday's book, Our Vanishing Wild Life assumed that this large, white crane had already gone the way of the recently-vanished Passenger Pigeon. After two seasons without any sightings of the Whooping Crane anywhere in North America, Hornaday credited the 14 June observation at Quill Lake as the last sighting by human eyes. 
The Greater Prairie Chicken or Pinnated Grouse had recently moved in from Minnesota and Manitoba to occupy the lush grass no longer grazed by bison. In 1909, Ferry reported that the Pinnated Grouse was as common as the Sharp-tailed Grouse, also but incorrectly called "prairie chicken", then as now. (The Pinnated Grouse disappeared in the 1930's).

The Upland Sandpiper, so common on the open prairie when the first settlers arrived, was already becoming uncommon by 1909 , but the Longbilled Curlew, a larger grassland representative of the wading birds, was still "abundant."

Mourning Doves had arrived from the southeast along with the settlers in the preceding years, but were still rare, with only four sightings of single birds recorded. Barn Swallows similarly were not yet common, for farm buildings were relatively new. The only barn swallow nests were "several . . . under a bridge at Quill Lake." A Purple Martin, lacking dead, hollow trees of sufficient size in the wild, had nested in the hollow eave of a settler's cabin at the north end of the lake. The House Sparrow, another new immigrant, was still rare, with only one sighting.

A Brown Thrasher nest found by a settler that year was one of the first ever reported in Saskatchewan. Before farm shelter belts grew up, and before trees were planted along village streets, the American Robin was a rare resident.

Ducks and geese were then common, with geese still evading the settlers' guns and egg-collecting on their island nest sites. Coots or mudhens were then rare in the sloughs near the lakes.

Their greatest thrill was to visit the islands in Big Quill and Middle Quill Lakes, teeming with colonial bird life. There were in 1909 no less than seven Common Tern colonies on seven islands, three Double-crested Cormorant colonies of more than 50 nests each, and a large White Pelican colony with several hundred nests on the extreme south island on Big Quill Lake.

Ferry, who had been born 12 October 1877 , had his promising career terminated abruptly at the age of 32 years, when he died of pneumonia on 11 February 1910, less than six months after returning from Saskatchewan. Barnes, fifteen years his senior, having been born 21 April 1862, had just become editor that year of The Oologist, a monthly magazine dealing with egg-collecting. Egg-collecting was then a more popular hobby than collecting postage stamps or coins. Barnes continued publishing The Oologist until he was 80 years of age, and died on 18 July 1945. He had life-long memories of one of Canada's finest wildlife habitats, but he did not return.

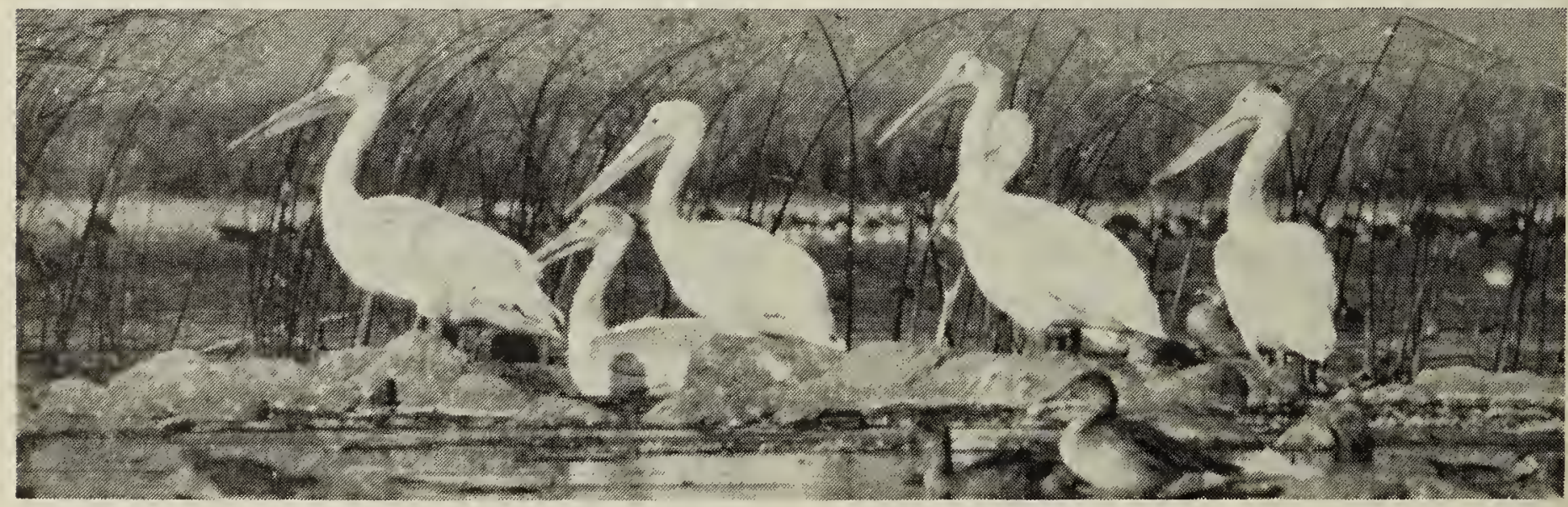

